HALSZKA GÓRNY

https://orcid.org/0000-0002-2440-4697

halszka.gorny@ijp.pan.p1

Instytut Języka Polskiego PAN

Kraków, Polska
DOI: http://dx.doi.org/10.17651/ONOMAST.64.9

Onomastica LXIV, 2020

PL ISSN 0078-4648

\title{
CZY ISTNIEJE POTRZEBA LEKSYKOGRAFICZNEGO OPRACOWANIA TERMINÓW ANTROPONOMASTYCZNYCH?
}

Słow a tematyczne: antroponomastyka, słownik terminów, struktura artykułu hasłowego, etnonim

\section{WSTĘP}

„Terminologia jest warunkiem działalności naukowej, a jej jakość (zwłaszcza precyzja i systemowość) wpływa w znacznej mierze na jakość wyników pracy badacza" - tak o istocie i roli terminologii pisała Ewa Wolnicz-Pawłowska w artykule zamieszczonym w 60. numerze „Onomastików” (2016, s. 37-46). W kontekście słów cenionej onomastki potrzeba systematyzacji i harmonizacji polskiej terminologii onomastycznej wydaje się niezbędna. Dlatego też pod auspicjami Sekcji Onomastycznej Komitetu Językoznawstwa PAN w kadencji 2015-2019 podjęto kolejną już próbę opracowania terminów w ramach międzyinstytucjonalnego projektu „Polska terminologia onomastyczna”. Postulowanym efektem końcowym miał być słownik, w którym w układzie hierarchiczno-tematycznym (zob. Bijak, 2019, s. 44-52) planowano zamieścić poszczególne terminy wraz z ich definicjami, pochodzeniem, wskazaniem wariantywnych postaci terminów (terminów równoważnych) i wariantywnych definicji, podaniem przykładów użycia, zmian znaczeniowych, uzusu, frekwencji i zaleceń poprawnościowych (termin preferowany, dopuszczalny, niezalecany), a także uwzględnić aspekty dodatkowe (stosowanie terminów niepoprawnych ortograficznie, funkcjonowanie terminów

${ }^{1}$ Podejmowane wcześniej próby opracowania polskich terminów onomastycznych nie przyniosły zadowalających wyników. Z taką inicjatywą wystąpiły m.in. Zofia Abramowicz i Leonarda Dacewicz, które na łamach „Onomastików” (1995, s. 247-253) zgłosiły konieczność systematyzacji terminów i wskazały podstawowe założenia słownika terminologicznego. 
w świadomości użytkowników języka itp.). Należy mieć nadzieję, że ponownie ukonstytuuje się Komisja Onomastyczna przy Komitecie Językoznawstwa PAN, a w jej ramach kontynuowane będą dotychczasowe prace.

$\mathrm{W}$ artykule omówione zostaną podstawowe zagadnienia związane $\mathrm{z}$ rozwojem, zasobem, frekwencją polskiej terminologii antroponomastycznej z uwzględnieniem wariantywności jednostek terminologicznych, współwystępowania form rodzimych i obcych (greckich, łacińskich). Na wybranym przykładzie przedstawiona zostanie wstępna koncepcja artykułu hasłowego w słowniku terminologicznym. Wśród wykorzystanych źródeł znajdują się m.in.: słownik „Osnoven sistem i terminologija na slovenskata onomastika” (Vidoeski i in., 1983), artykuł Mieczysława Karasia „W sprawie polskiej terminologii onomastycznej” (1968, s. 352-360), opracowania Henryka Górnowicza (1988) i Ewy Jakus-Borkowej (1987), encyklopedia „Polskie nazwy własne” (Rzetelska-Feleszko, 1998) i kompendium „Słowiańska onomastyka” (Rzetelska-Feleszko, Cieślikowa i Duma, 2002-2003) oraz wybrane artykuły publikowane na łamach pisma „Onomastica”, a także „Rocznika Slawistycznego" i „Rozpraw Komisji Językowej WTN”.

\section{ROZWÓJ I ZASÓB TERMINÓW ANTROPONOMASTYCZNYCH — ZARYS}

W artykule „Polish Anthroponomastic Terminology — Towards Systematization and Normalization" (Górny, 2019, s. 105-117) podałam wstępne dane dotyczące liczby funkcjonujących współcześnie terminów w pracach z zakresu antroponomastyki (ok. 300). Wśród nich znajdują się terminy onomastyczne i ogólnojęzykoznawcze, a obok jednostek nadrzędnych wskazać można liczne określenia podrzędne z elementami dyferencyjnymi. W słowniku hierarchiczno-tematycznym powinien być zachowany kilkustopniowy układ hiperonimiczno-hiponimiczny, a zatem jednostki podrzędne (często dwuskładnikowe) miałyby być wyszczególnione pod odpowiednim hasłem głównym, np.

\footnotetext{
antroponim / nazwa osobowa - antroponimia (zbiór antroponimów) nazwa indywidualna

imię

imię indoeuropejskie; imię rodzime // stowiańskie // staropolskie ( $\rightarrow$ imię dwuczłonowe (złożone), imię jednotematowe // apelatywne); imię zapożyczone ( $\rightarrow$ imię chrześcijańskie $\rightarrow$ imię biblijne $\rightarrow$ imię starotestamentowe, imię nowotestamentowe, imię osoby świętej; imię świeckie) oraz imię hipokorystyczne // pieszczotliwe // hipokorystyk // hypocoristicum, imię apotropeiczne, imię derywowane itp.

nazwa rodzinna, rodowa, zbiorowa nazwisko

nazwisko odapelatywne, nazwisko odimienne, nazwisko odmiejscowe, nazwisko patronimiczne (odojcowskie), nazwisko odetniczne itp.
} 
W terminologii naukowej obserwuje się zmiany związane z pojawianiem się nowych terminów i określeń wariantywnych przy jednoczesnym stopniowym zaniku terminów rzadko używanych. W tym kontekście warto zarysować rozwój polskiej terminologii antroponomastycznej, odwołując się do najważniejszych opracowań. Jednym z nich z pewnością jest zbiór słowiańskich terminów onomastycznych „Osnoven sistem” (1983) zawierający 220 terminów polskich, w tym ponad 50 terminów antroponomastycznych. Wśród nich znajdują się określenia, które nie przyjęły się i nie są używane w pracach polskich onomastów (np. antroponimika, nazwa dziecięca, nazwa chłopięca, nazwa dziewczęca, imiennik). W słowniku tym terminy zaklasyfikowano do dwóch nadrzędnych grup: terminy onomastyczne dla nazw własnych oznaczających różne typy obiektów (tu: bionimy i abionimy) oraz terminy dotyczące opisu i opracowania nazw własnych. W pierwszej grupie (w ramach bionimów) zamieszczono 14 terminów odnoszących się do nazewnictwa osobowego. Wyróżniono: antroponim $\rightarrow$ nazwa osobowa $\rightarrow$ nazwa męska, nazwa żeńska, nazwa dziecięca (nazwa chłopięca, nazwa dziewczęca); nazwa grupowa // antroponim zespołowy $\rightarrow$ nazwisko rodzinne, nazwa rodowa, nazwa mieszkańca, etnonim // nazwa etniczna oraz pseudoantroponim $\rightarrow$ teonim // nazwa bóstwa. Wśród terminów dotyczących opisu i opracowania nazw własnych wskazano antroponimika, a w wyniku dalszej hierarchizacji terminy w obrębie takich działów jak: powstanie i rozwój antroponimów (5, np. antroponimizacja, antroponimia, pseudoginim), antroponimy z formalnego punktu widzenia (3, np. antropoleksem, formant antroponimiczny // antropoformant), systemy antroponimiczne i ich funkcjonowanie (4, np. mononimia, polionimia), metodyka antroponomastyki ( $3, \mathrm{np}$. antroponomasta, antroponomastykon), terminy związane z nazwami osobowymi (6, np. nazwa patronimiczna // odojcowska, nazwisko metronimiczne, nazwisko ginekonimiczne), leksykalno-semantyczne aspekty nazw osobowych (1: apotropajon // nazwa opiekuńcza (profilaktyczna)), nazwy osobowe z formalnego punktu widzenia (3, np. nazwisko odapelatywne, nazwisko deantroponimiczne), systemy nazw osobowych i ich funkcjonowanie (9, np. imię chrzestne, imię kościelne, przydomek, nazwisko), terminy etnonomastyczne (4: etnonimizacja, deetnonimizacja, etnonim endogeniczny, etnonim egzogeniczny), zob. niżej.

A.

1. bionim

11 antroponim

111 nazwa osobowa

1111 nazwa męska

1112 nazwa żenska

1113 nazwa dziecięca

11131 nazwa chtopięca

11132 nazwa dziewczęca 
112 nazwa grupowa // antroponim zespołowy

1121 nazwisko rodzinne

1122 nazwa rodowa

1123 nazwa mieszkańca

1124 etnonim // nazwa etniczna

12 pseudoantroponim

121 teonim // nazwa bóstwa

B.

11 antroponimika (adj. antroponimiczny)

11.1 Powstanie i rozwój antroponimów

11.12.1 antroponimizacja

11.12.2 deantroponimizacja

11.13 antroponimia (zbiór antroponimów danego języka, okresu, regionu)

11.19.11.1 pseudoginim

11. 19.11.2 pseudoandronim

11.3 Antroponimy z formalnego punktu widzenia

11.33.12.01 antropoleksem

11.33.12.02 formant antroponimiczny // antropoformant

11.33.3 imiennik

11.4 Systemy antroponimiczne $i$ ich funkcjonowanie

11.40.1 mononimia

11.40.2 polionimia

11.40.21 dionimia

11.40.22 trionimia

11.9 Metodyka antroponomastyki

11.91.1 antroponomasta (osoba zajmująca się badaniem antroponimii)

11.91.2 antroponomastykon (spis antroponimów w formie książki z lingwistycznymi

(i pozalingwistycznymi) objaśnieniami)

11.91.3 atlas antroponomastyczny

111 Terminy związane z nazwami osobowymi

111.20.13.01 nazwa patronimiczna // odojcowska

111.20.13.01 nazwa metronimiczna

111.20.13.12.1 nazwisko patronimiczne

111.20.13.12.2 nazwisko metronimiczne

111.20.13.12.3 andronim

111.20.13.12.4 nazwisko ginekonimiczne

111.21 Leksykalno-semantyczne aspekty nazw osobowych

111.21.91 apotropajon // nazwa opiekuńcza (profilaktyczna)

111.3 Nazwy osobowe $\mathrm{z}$ formalnego punktu widzenia

111.31.1 nazwisko odapelatywne

111.31.21.1 nazwisko deantroponimiczne

111.31.22.1 nazwisko odtoponimiczne

111.4 Systemy nazw osobowych i ich funkcjonowanie

111.40.10.1 mononim

111.40.20.1 imię chrzestne

111.40.20.11 imię kościelne

111.40.20.11 imię kalendarzowe

111.40.20.2 nazwa wyróżniająca

111.40.20.21 przydomek

111.40.20.3 nazwisko 
111.40.20.4 nazwa odojcowska

111.40.20.5 nazwa oddomowa

1124 Terminy etnonomastyczne

1124.1 Powstanie i rozwój etnonimów

1124.12.1 etnonimizacja

1124.12.2 deetnonimizacja

1124.14.1 etnonim endogeniczny

1124.14.4 etnonim egzogeniczny (Osnoven sistem)

Prace nad glosariuszem „Osnoven sistem”, który ukazał się w 1983 r., zostały zainicjowane przez Jana Svobodę w latach 60. XX w. W 1968 r. ukazał się tekst Mieczysława Karasia, w którym autor przedstawił, w nawiązaniu do propozycji Svobody, wstępny projekt polskiej terminologii onomastycznej. Terminy (niekiedy wraz z przykładami) zestawił w czterech grupach: nazwa własna - ogólnie, nazwa własna miejscowa, nazwa własna przedmiotowa (prócz miejscowości), nazwa własna osobowa (istot żywych). W ostatniej z nich wyróżnił niemal 90 terminów w kilku podgrupach, takich jak:

a) zjawiska i typy morfologiczne, np. nazwa prosta - Piotr, Wilk, nazwa złożona - Dobrogost, nazwa pieszczotliwa - Staś, nazwa wywoławcza Władziu;

b) zjawiska fonetyczne, np. geminacja spieszczeniowa;

c) znaczeniowe typy nazw osobowych, np. nazwa od właściwości duchowych, nazwa od okoliczności (czas urodzenia, liczba dzieci), przezwisko od mająt$k u$, nazwisko etnonimiczne, nazwa fytonimiczna;

d) inne rodzaje nazw osobowych, np. nazwa reformacyjna, nazwa kontrreformacyjna, nazwa humanistyczna, nazwa sakralna (mitologiczna), nazwa wróżebna (totemiczna);

e) nazwa alegoryczna (zmyślona), np. nazwa boska (demoniczna),

f) nazwa zbiorowa, np. nazwa skupiskowa - Spartakus, nazwa od czéści świata-Azjaci, przezwiska terytorialne — Górale, Galileusze.

W propozycji M. Karasia nie pojawia się termin imię (jest: nazwa chrzestna, nazwa odróżniająca (drugie imiona)) ani określenia względem niego podrzędne typu imię staropolskie, chrześcijańskie. Wyszczególnione są natomiast różne typy nazwisk, np. nazwisko odapelatywne, odimienne, patronimiczne i metronimiczne (Sterczula), odmiejscowe, rodowe (Jagiellonowie), rodzinne (Nowakowie), w obrębie przezwisk - określenia: nazwa żartobliwa i przezwisko rodzinne, a kryptonim i fiktonim w ramach hiperonimu pseudonim. Część terminów proponowanych przez Karasia (w dużym stopniu będących polskimi odpowiednikami propozycji J. Svobody) się nie przyjęła (np. nazwa dziecinna (pajdonimiczna)), inne z kolei zostały z czasem rozbudowane o liczne określenia podrzędne. W pracy Karasia zwracają ponadto uwagę określenia wieloskładnikowe, np. nazwa dziecka spoza matzeństwa, nazwa plemienna jako narodowa, nazwa od wyrobów, naczyń, materiatów. 
W syntezach onomastycznych z lat 80 . XX w. autorstwa E. Jakus-Borkowej (1987) i H. Górnowicza (1988) obserwujemy dalszy rozwój terminologii antroponomastycznej. Rozłącznie stosowane są tu już terminy antroponomastyka 'nauka o zbiorze nazw osobowych' i antroponimia 'zbiór nazw osobowych' (terminy zalecane). W wymienionych podręcznikach obok terminów podstawowych (imię, nazwisko itp.) funkcjonują terminy podrzędne (liczniejsze w pracy E. Jakus-Borkowej), np.

imię - staropolskie (obserwacyjne // odapelatywne, życzeniowe // dwuczłonowe), chrześcijańskie, hipokorystyczne, skrócone, imiesłowowe, melioratywne, metrykalne, modne, „mówiace”, znaczace (Jakus-Borkowa, 1987);

imię - staropolskie (jednoczłonowe, dwuczłonowe, imiesłowowe, skrócone, pieszczotliwe (hipokorystyka)), chrześcijańskie (Górnowicz, 1988).

Wiele $\mathrm{z}$ nich znalazło zastosowanie $\mathrm{w}$ pracach polskich onomastów. Podobnie jak używane przez autorów terminy nazwy prymarne (bezprzyrostkowe) i nazwy sekundarne (przyrostkowe, pochodne). Krytyka tych ostatnich pojawiła się dość wcześnie (zob. np. Kowalik-Kaleta, 1983, s. 231-254), mimo to przez długi czas stosowane były w opracowaniach onomastycznych w utrwalonym, lecz błędnym znaczeniu.

Bogaty zbiór terminów i quasi-terminów antroponomastycznych (niemal 300) zawiera encyklopedia „Polskie nazwy własne” (1998). Obejmuje on terminy typowo antroponomastyczne i ogólnojęzykoznawcze, rodzime i obce (greckie, łacińskie), a wśród licznych określeń jedno- i więcejwyrazowych znajduje się słownictwo niebędące terminami. Zwracają uwagę liczne terminy podrzędne względem takich hiperonimów terminologicznych jak: imiona, nazwiska, etnonimy, pseudonimy, przezwiska itp., które wyróżniane są m.in. ze względu na czynnik genetyczny, wpływy obce, strukturę, sytuację komunikacyjną.

Obrazu polskiej terminologii antroponomastycznej nie zmieniają terminy przytoczone w syntezie „Słowiańska onomastyka” (2002-2003), w części dotyczącej onomastyki w Polsce (jest ich jednak zdecydowanie mniej). Z kolei lista kluczowych terminów onomastycznych, ustalona przez grupę terminologiczną ICOS, a przetłumaczona i opracowana przez Artura Gałkowskiego i Urszulę Bijak obejmuje kilkadziesiąt terminów onomastycznych, w tym zaledwie kilkanaście jednostek odnoszących się do antroponimii: antroponimia, antroponomastyka, antroponomastykon, etnonim, hagionim, imię, nazwa mieszkańca, nazwisko, przezwisko, pseudonim, teonim. W wypadku kilku z nich dopuszczono określenia wariantywne: antroponim // nazwa osobowa, hipokorystyk // hipokorystykum, matronimikum // matronimicum // matronimik, patronim // patronimikum.

W wydawnictwach encyklopedycznych zawierających hasła z zakresu językoznawstwa ogólnego i polonistycznego (EJO i EJP) odnajdujemy nieliczne 
terminy dotyczące antroponimów. Pojawia się w nich określenie antroponimia (brak: antroponim, antroponomastyka, antroponomastykon), ale w niezalecanym znaczeniu 'dział onomastyki zajmujący się nazwami osobowymi'. Pozostałe terminy w „Encyklopedii języka polskiego” (1999) (ok. 13) to określenia jednoskładnikowe (imię, nazwisko, przezwisko, pseudonimy) oraz dwu- (imiona chrzestne, imiona osób, imiona słowiańskie, nazwisk kobiet) i wieloskładnikowe (nazwiska obcego pochodzenia, nazwy herbów i zawołania, nazwy mieszkańców osad, nazwy plemienne Słowian). Zasób terminów onomastycznych w „Encyklopedii językoznawstwa ogólnego" (wyd. II z 1999 r.) jest uboższy. Pojawiają się tu m.in. określenia: imię własne jako synonim nazwy własnej // nomen proprium czy termin nieużywany przez onomastów patronimikon, definiowany jako ‘imię (nazwa) własne utworzone od imienia ojca lub przodka', który odnosi się do nazwisk typu Jakubowicz i nazw miejscowych typu Janowice.

Z krótkiego zarysu rozwoju i zasobu terminów antroponomastycznych wynika, że mamy do czynienia ze zbiorem obejmującym obecnie z pewnością ponad 250 jednostek, wśród których wskazać można terminy zalecane, przestarzałe, niezalecane. Wiele terminów nieużywanych przez onomastów w Polsce zostało zaproponowanych w artykule M. Karasia i w „Osnoven sistem” (1983). Niemniej jednak „Osnoven sistem” i podręcznik „Polskie nazwy własne” są głównym źródłem terminów z zakresu onomastyki. W encyklopediach nieonomastycznych (EJO, EJP) uwzględnione są jedynie podstawowe określenia odnoszące się do nazw osobowych, które stanowią niewielki odsetek pozostałych haseł. W tej kategorii terminologicznej zwraca uwagę niski przyrost neologizmów, występowanie form wariantywnych (ananim // anagramonim // palinonim 'pseudonim powstały w wyniku przestawienia kolejności liter w nazwisku, imieniu lub pseudonimie', zob. Zawodzińska-Bukowiec, 2014), dublety z liczbą gramatyczną (np. nazwisko, nazwiska), liczne dwu- lub kilkuczłonowe terminy podrzędne. Zdarzają się terminy homonimiczne, wspólne dla dwóch podgrup nazw własnych: antroponimów i toponimów (np. patronimikum czy nazwa etniczna).

\section{ETNONIM // NAZWA ETNICZNA - HISTORIA TERMINU, DEFINICJE, STATUS}

Wśród terminów antroponomastycznych wskazać można jednostki odnoszące się do nazw indywidualnych (imię, przezwisko, pseudonim) oraz określenia rozpatrywane w ramach nazw rodzinnych i zbiorowych. W ostatniej grupie - obok nazwiska, nazwy heraldycznej, nazwy dynastycznej — wymienić należy etnonim i jego synonimiczny wariant nazwe etniczna. W wyniku dalszej hierarchizacji wskazać można terminy podrzędne z elementami dyferencyjnymi oraz ich warianty, np. etnonim egzogeniczny // egzoetnonim, etnonim endogeniczny 
// endoetnonim, etnonim odtoponimiczny // etnonim pochodzenia topograficznego, etnonim odimienny. Podkreślić należy, że etnonim nie należy do prototypowych terminów onomastycznych ze względu na niejednoznaczną przynależność wyznaczanych przez niego jednostek do kategorii nazw własnych. W literaturze przedmiotu niejednolicie określany jest też jego zakres.

Prześledźmy zatem historię i definicje terminu (na podstawie wybranych opracowań) ze zwróceniem uwagi na typy nazw, jakie obejmuje. W SJP PWN termin ten definiowany jest jako 'wyraz będący nazwą narodu, plemienia', w WSJP PAN jako 'nazwa narodu, plemienia lub grupy etnicznej' (por. SJPDor 'nazwa narodowa, plemienna, np. Włoch, Polanin, Kurp'). Określenie to nie pojawia się w polskich encyklopediach ogólnojęzykoznawczych (EJP i EJO). W EJP mowa jest co prawda o nazwie etnicznej, ale w odniesieniu do nazw miejscowych typu Zagórzany, Brzeżany ${ }^{2}$.

Termin etnonim // nazwa etniczna nie został użyty przez Witolda Taszyckiego w artykule „O nazwach Śląsk i Ślężanie” (1946/1958a) (tu: autor posłużył się określeniem nazwa plemienna) ani w tekście „Kilka uwag o nazwach mieszkańców od nazw krain i miejscowości" (1964/1968). Autor nazwy plemienne, narodowe i nazwy mieszkańców uznawał za wyrazy pospolite: ,wiążą się one [nazwy narodowe, plemienne i nazwy mieszkańców] najściślej z wyrazami pospolitymi i jedną z nimi tworzą całość. [...] Jeżeli w pewnych językach, np. w języku polskim, niektóre spośród tych wyrazów zewnętrznie się traktuje jak imiona własne, pisząc je przez wielką literę (Czech, Francuz, Niemiec; Kujawianin, Mazur, Śląak), nic to nie znaczy" (Taszycki, 1964/1968, s. 51).

W propozycji terminologicznej Mieczysława Karasia (1968) także nie odnajdziemy określenia etnonim; przymiotnik etniczny pojawia się w grupie nazw geograficznych (nazwa etniczna, np. Wegrzce, nazwa pseudoetniczna, np. Niemce < nazwiska Niemiec), a etnonimiczny — w zbiorze nazwisk (nazwisko etnonimiczne). Wymienione są tu jednak terminy: nazwa od części świata (Azjaci), nazwa narodowa (Polacy), nazwa odplemienna (Górale), nazwa mieszkańca (Krakowianie), które rozpatrywać można (choć nie bez zastrzeżeń) w ramach etnonimów.

Z kolei Stanisław Rospond $(1966,1969)$ w pracy poświęconej strukturze pierwotnych nazw plemion słowiańskich (np. Obodrzycy, Brzeżanie, Wiercanie) posługuje się zarówno terminami etnonim, etnonimia, jak i określeniami synonimicznymi (nazwa etniczna // struktura etnonimiczna) oraz terminami podrzędnymi z członami wskazującymi na pochodzenie lub budowę nazwy (etnonim topograficzny, etnonim antroponimiczny, etnonim sekundarny). Używa również określenia baza etnonimiczna (np. Srb- dla nazwy Serbowie).

2 Tego typu nazwy etniczne zdefiniował W. Taszycki jako „oznaczające w najdawniejszym stanie rzeczy mniejszą lub większą gromadę ludzką, na podstawie właściwości zamieszkanego przez nią skrawka ziemi, pochodzenia z pewnej okolicy lub miejscowości” (Taszycki, 1946/1958b, s. 262). 
Pod koniec lat 60. XX w. ukazało się opracowanie struktury nazw etnicznych w języku polskim autorstwa Małgorzaty Sulisz (1969). Już z pierwszego zdania tekstu wynika sposób definiowania etnonimu // nazwy etnicznej: „Celem pracy jest analiza budowy słowotwórczej polskich etnonimów, czyli nazw mieszkańców, w ujęciu chronologicznym" (Sulisz, 1969, s. 287). Do nazw mieszkańców zalicza onimy typu: Słowianin, Egipcjanin, Galicjanin, Polanin, Krakowianin, Rusin, Żydowin; Litwiniec, Stowak, Ślazak, warszawiak, Rusek, Moskal, Żyd itp., a zatem zarówno nazwy mieszkańców krajów, miast, regionów, jak i nazwy plemienne i narodowe. Etnonimię traktuje jako dział onomastyki (termin niezalecany w tym znaczeniu - H.G.), nie jako zbiór etnonimów, a synonimicznym określeniem etnonimu // nazwy etnicznej jest tu formacja etnonimiczna. Mowa jest także o przyrostku w funkcji etnonimicznej, etnonimach typu topograficznego (Wiślanie $<$ Wisła) i nazwach pochodzenia osobowego (Dziadoszycy< < n. os. Dziadosz).

Według Zofii Kowalik-Kalety (1982) nazwy mieszkańców i tzw. etnika to dwie odrębne kategorie: „Pierwsze odnoszą się do pojedynczych osób zamieszkujących dany kraj, obszar etniczny lub miasto albo też należących do danego plemienia. Drugie to nazwy plemion i narodów" (1982, s. 39). Etnikami w jej ujęciu nie są nazwy typu Mazowszanin, Francuz, Polanin, warszawiak — sytuowane na granicy apelatywów i nazw własnych (nie identyfikują jednostki, lecz członka grupy społecznej), ale nazwy kolektywne typu Polanie, Wieleci, Wegrzy.

E. Jakus-Borkowa (1987) terminem etnonimy // nazwy etniczne obejmuje nazwy plemion oraz większych i mniejszych grup etnicznych (w wypadku współczesnych etnonimów - nazwy obywateli państw i członków narodowości oraz społeczeństw, a także określenia mieszkańców miast, wsi, dzielnic, regionów), a etnonimię rozumie raczej jako dział onomastyki zajmujący się etnonimami niż jako zbiór etnonimów. Ze względu na pochodzenie wyróżnia etnonimy utworzone od warunków topograficznych terenu (np. Lędzicy) oraz od cech charakterystycznych mieszkańców (Mazurzy).

Wśród terminów zawartych w „Osnoven sistem” (1983) odnajdujemy w grupie antroponimów zbiorowych określenie etnonim // nazwa etniczna, a w punkcie terminy etnonomastyczne - etnonim endogeniczny i etnonim egzogeniczny (obok etnonimizacji i deetnonimizacji). Terminy z elementami dyferencyjnymi zostały objaśnione w opracowaniu „Polskie nazwy własne” (1998, s. 181), w którym czytamy: „Pierwotne wspólnoty wyłaniały swą nazwę w procesie samookreślenia się (autoidentyfikacji etnicznej — etnonimy endogeniczne) lub otrzymywały ją z zewnątrz, od sąsiadów (etnonimy egzogeniczne)". Wymienione zostały również inne terminy szczegółowe: etnonimy pochodzenia topograficznego (wskazujące na więź terytorialną), odimienne (więź krwi) i przezwiskowe (charakterystyczne cechy członków danej wspólnoty), a także określony został zakres terminu etnonim (nazwy plemion, nazwy grup regionalnych, nazwy narodowości, pluralne 
formy nazw mieszkańców). W kompendium „Słowiańska onomastyka” (20022003) do etnonimów włączono zarówno nazwy plemion, narodów, zbiorowości lokalnych, jak i nazwy mieszkańców regionów, miejscowości.

W świetle powyższych uwag związanych z rozwojem terminu etnonim (nazwa etniczna), jego zakresem i statusem onomastycznym celowe wydaje się wskazanie jego miejsca w terminologicznym słowniku hierarchiczno-tematycznym (wraz z terminami podrzędnymi) oraz podanie definicji i przykładów zastosowania:

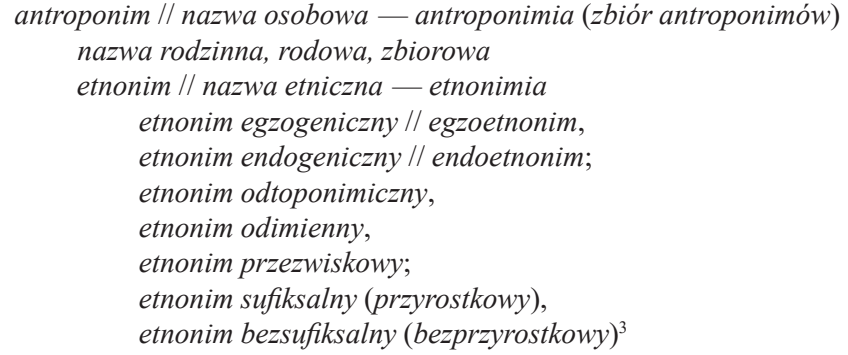

\section{WSTĘPNA STRUKTURA ARTYKUŁU HASŁOWEGO}

\section{TERMIN etnonim}

DEFINICJA 'nazwa własna grupy etnicznej (plemienia, narodu, ludu) bądź przedstawiciela takiej grupy'

\section{WARIANTYWNOŚĆ // TERMIN RÓWNOWAŻNY nazwa etniczna ${ }^{4}$}

POCHODZENIE // OBJAŚNIENIE gr. éthnos 'lud, naród, rasa, plemię' + gr. ónyma 'imię'

EKWIWALENT W JEZZYKU ANGIELSKIM ethnonym 'proper name of an ethnic group (a tribe, a folk, a clan etc.), or a member of this group, e.g. Italians, Bavarians, Croat, Frenchman, Zulu. (NOTE: Ethnonyms are not treated as proper names in some languages and by some scholars, e.g. ingleses in Spanish. According to some theories, ethnonyms are proper names both in plural and singular, in other theories, ethnonyms in the plural are proper names, in the singular appellatives.)' (List of Key Onomastic Terms)

\section{PRZYKLADY // ZASTOSOWANIE}

„Rodzimą warstwę etnonimów zbiorowych poza [...] nazwami prapolskich plemion, reprezentują późniejsze nazwy zbiorowości lokalnych, tj. nazwy wspólnot związanych z określonym terytorium regionalnym [...] np. Kociewiacy, Krakowiacy" (Polskie nazwy własne, s. 183).

${ }^{3}$ Niektórzy badacze (np. Tyrpa, 2012, s. 25-52) wyróżniają ponadto etnonimy męskie (Grek, Tatar, Rusnak), etnonimy żeńskie (Murzynka, Cyganicha), etnonimy dziecięce (Żydziatko) i etnonimy zbiorowe (gw. Litwa 'Litwini').

${ }^{4} \mathrm{~W}$ literaturze przedmiotu ze względów stylistycznych stosowane są też określenia typu: struktura etnonimiczna, formacja etnonimiczna, niemające jednak statusu terminu, a także etnika i nazwa odśrodowiskowa. W słowniku terminologicznym termin będzie też odesłany do hasła toponim. 
„Etnonimy są nazwami grup wspólnotowych, które łączą więzi społeczne, kulturowe, język, a także wspólnie zajmowany teren" (Słowiańska onomastyka, t. I, s. 479).

„Galicja była identyfikowana z Polską, dlatego tak właśnie nazywano ten region, a jej mieszkańców określano etnonimem Polacy" (Rak, 2015, s. 354).

„Część etnonimów jest motywowana nazwami pasm i szczytów górskich, np. Magurcanie i Babiogórcy [...], inne odwołują się do koloru stroju: Górále cýści (Podhalanie), biáli (w Gorcach, od strony Nowego Sącza) i cárni (okolice Piwnicznej), lub poszczególnych jego elementów: Guńkárze (na Śląsku Cieszyńskim nazwa górali ubierających się w guńki) i Siercanie (Podhalanie, od sieraka ‘opończy z kapturem') [...]” (Rak, 2015, s. 47).

„Językoznawcy dokonują w zakresie etników rozróżnienia na nazwy etniczne, rozumiane jako nazwy plemion i narodów oraz nazwy mieszkańców, odnoszące się do «pojedynczych osób zamieszkujących dany kraj lub miasto albo też należących do danego plemienia» [...]. W artykule tym będziemy posługiwać się wymiennie wspomnianymi wyżej terminami, a także niekiedy stosować szerszy — nazwa odśrodowiskowa" (Zarębski, 2003, s. 48).

„Etnonimy. Nazwy członków narodów lub grup etnicznych [...]” (Tyrpa, 2012, s. 34).

KONTEKST UŻYCIA Termin pojemny, stosowany w odniesieniu do nazw plemion, narodów, ludów, nazw mieszkańców regionów, a także miejscowości.

ASPEKTY DODATKOWE Status etnonimów nie jest jednoznaczny. W niektórych językach oraz przez niektórych badaczy etnonimy nie są uznawane za nazwy własne. Wedle niektórych teorii etnonimy są nazwami własnymi tylko w $\mathrm{lm}$., w lp. nimi nie są, według innych przynależą do propriów niezależnie od tego, czy mają postać pluralną czy singularną (zob. Lista słów kluczowych w onomastyce).

Terminami podrzędnymi względem hiperonimu etnonim są m.in. etnonim endogeniczny i etnonim egzogeniczny wraz z dopuszczalnymi wariantywnymi formami syntetycznymi: endoetnonim i egzoetnonim. Wstępnie można je zdefiniować następująco:

etnonim endogeniczny// endoetnonim 'nazwa własna grupy etnicznej (plemienia, narodu, ludu) powstała w procesie autoidentyfikacji etnicznej (samookreślenia się) i używana przez przedstawicieli danej grupy',

etnonim egzogeniczny // egzoetnonim 'nazwa własna grupy etnicznej (plemienia, narodu, ludu) nadana przez przedstawicieli obcej wspólnoty etnicznej'.

Powyższe eksplikacje uzasadnia użycie tych terminów w opracowaniach onomastycznych i dialektologicznych, np.

Nazwy wspólnot, a więc plemion narodów, zbiorowości lokalnych, mieszkańców regionów, miejscowości, powstawały jako nazwy wychodzące od danej grupy (etnonimy endogeniczne), np. według przekonania niektórych badaczy do takich etnonimów należą Słowianie 'ludzie mówiący zrozumiale' [...] i etnonimy endogeniczne [sic! powinno być egzogeniczne - H.G.] powstałe na podstawie opozycji swoi: obcy, np. Niemcy (Słowiańska onomastyka, t. I, s. 479). 
Góral w ujęciu historycznym należy do egzoetnonimów. Pierwotnie było to przezwisko [...] utworzone za pomocą augmentatywnego sufiksu -al od podstawy góra 'większe wzniesienie terenu' (Rak, 2015, s. 48).

J.S. Bystroń, omawiając pochodzenie etnonimów, dużo miejsca poświęcił nazwom motywowanym górzystością lub nizinnością terenu. Przede wszystkim scharakteryzował nazwy mieszkańców polskiej i ukraińskiej części Karpat. Dowiadujemy się więc, że w przypadku górali ruskich mamy rozbieżność między egzoetnonimami a endoetnonimami, por.: Łemkowie Rusnacy, Bojkowie - Hyrniacy, Wyrchowyńcy (Rak, 2015, s. 47).

\section{PODSUMOWANIE}

Zarysowany w artykule rozwój i zasób terminologii antroponomastycznej (na podstawie wybranych kompendiów, opracowań monograficznych i przyczynkarskich), a także przedstawiona koncepcja słownikowego opracowania polskiej terminologii onomastycznej i wstępna struktura artykułu hasłowego etnonim wskazują na problemy związane $\mathrm{z}$ definiowaniem terminu, wyznaczeniem jego zakresu, ustaleniem statusu (w jednostkowych przypadkach), określeniem preferowanych, dopuszczalnych i niezalecanych postaci wariantywnych, wyborem (redukcją) terminów podrzędnych, akceptacją lub nie neoterminów itp. W tym kontekście twierdząco należy odpowiedzieć na pytanie postawione w tytule niniejszego tekstu i podjąć działania zmierzające do całościowego opracowania (systematyzacji, normalizacji, harmonizacji) terminologii w ramach poszczególnych subdyscyplin onomastyki.

\section{LITERATURA}

Abramowicz, Z. i Dacewicz, L. (1995). Założenia słownika polskiej terminologii onomastycznej [Foundations of the dictionary of Polish onomastic terminology]. Onomastica, 40, 247-253.

Bijak, U. (2019). Polska terminologia onomastyczna. Ku harmonizacji systemu [Polish onomastic terminology. Towards the harmonization of the system]. W: A. Chomová, J. Krško, I. Valentová (red.), Konvergencie a divergencie v propriálnej sfére. 20. slovenská onomastická konferencia. Banská Bystrica 26.-28. júna 2017. Zbornik referátov [Convergence and divergence in the proprial sphere. Proceedings of the 20th Slovak Onomastic Conference. Banská Bystrica 26-28 June 2017] (s. 44-52). Bratislava: VEDA.

EJO - Polański, K. (red.). (1999). Encyklopedia językoznawstwa ogólnego (wyd. 2) [Encyclopedia of general linguistics (2nd edition)]. Wrocław-Warszawa-Kraków: Zakład Narodowy im. Ossolińskich.

EJP — Urbańczyk, S. (red.). (1999). Encyklopedia języka polskiego (wyd. 3) [Encyclopedia of the Polish language (3rd edition)]. Wrocław-Warszawa-Kraków: Zakład Narodowy im. Ossolińskich.

Górnowicz, H. (1988). Wstęp do onomastyki [Introduction to onomastics]. Gdańsk: Wydawnictwo Uniwersytetu Gdańskiego. 
Górny, H. (2019). Polish Anthroponomastic Terminology - Towards Systematization and Normalization. Annales Universitatis Mariae Curie-Skłodowska. Sectio FF, 37, 105-117.

Grupa Terminologiczna ICOS. (2018). Lista ICOS kluczowych terminów onomastycznych (thum. i oprac. w języku polskim A. Gałkowski, U. Bijak). http://onomastyka.uni.lodz.pl/wp-content/ uploads/2019/03/Lista-ICOS-kluczowych-terminów-onomastycznych.pdf (dostęp: 13.04.2020).

ICOS Terminology Group. (b.d.). List of Key Onomastic Terms. https://icosweb.net/wp/wp-content/uploads/2019/05/ICOS-Terms-en.pdf (dostęp: 13.04.2020).

Jaku s-Borkowa, E. (1987). Nazewnictwo polskie [Polish names and naming]. Opole: WSP w Opolu.

Karaś, M. (1968). W sprawie polskiej terminologii onomastycznej [On Polish onomastic terminology]. Onomastica, 13, 352-360.

Kowalik-Kaleta, Z. (1982). Miejsce kategorii nazw mieszkańców (Polanin, Francuz, Warszawiak) oraz etników (Wiślanie, Litwini) w systemie językowym [Names of inhabitants (Polanin, Francuz, Warszawiak) and ethnic groups (Wiślanie, Litwini) in the language system]. Onomastica, 27, 39-53.

Kowalik-Kaleta, Z. (1983). Strukturalistyczna a strukturalna klasyfikacja nazwisk [Structuralist and structural classification of surnames]. Polonica, 9, 231-254.

Osnoven sistem - Vidoeski, B. i in. (red.). (1983). Osnoven sistem i terminologija na slovenskata onomastika. Osnovnaja sistema i terminologija slavjanskoj onomastiki. Grundsystem und Terminologie der slawischen Onomastik. Skopje: Makedonska akademija na naukite i umetnostite.

Polskie nazwy własne - Rzetelska-Feleszko, E. (red.). (1998). Polskie nazwy własne. Encyklopedia [Polish proper names. Encyclopedia]. Warszawa-Kraków: Towarzystwo Naukowe Warszawskie; Instytut Języka Polskiego PAN.

Rak, M. (2015). Kulturemy podhalańskie [Podhale culturemes]. Kraków: Księgarnia Akademicka.

Rospond, S. (1966). Struktura pierwotnych etnonimów słowiańskich. Cz. I [Structure of the original Slavic ethnonyms. Part 1]. Rocznik Slawistyczny, 26, 21-34.

Rospond, S. (1969). Struktura pierwotnych etnonimów słowiańskich. Cz. II [Structure of the original Slavic ethnonyms. Part 2]. Rocznik Slawistyczny, 29, 9-28.

Słowiańska onomastyka — Rzetelska-Feleszko, E., Cieślikowa, A. i Duma, J. (red.). (20022003). Słowiańska onomastyka. Encyklopedia (t. 1-2) [Slavic onomastics. Encyclopedia (Vols. 1-2)]. Warszawa-Kraków: Towarzystwo Naukowe Warszawskie.

S JPD or — Doroszewski, W. (red.). (1969). Stownik języka polskiego (wersja cyfrowa) [Dictionary of the Polish language (electronic version)]. https://sjp.pwn.pl/doroszewski/lista

S JP PWN — Słownik języka polskiego PWN (uzupełniona i poprawiona cyfrowa wersja Słownika 100 tysięcy potrzebnych słów, red. J. Bralczyk, Warszawa 2005) [Dictionary of the Polish language PWN]. https://sjp.pwn.pl/

Sulisz, M. (1969). Budowa słowotwórcza nazw etnicznych w języku polskim [Word-formation of ethnic names in the Polish language]. Rozprawy Komisji Językowej WTN, 7, 287-341.

Taszycki, W. (1958a). O nazwach Śląsk i Ślężanie [About the names Śląsk and Ślężanie]. W: W. Taszycki, Rozprawy i studia polonistyczne (t. I, s. 332-333). Wrocław — Kraków: Zakład Narodowy im. Ossolińskich. (Przedruk z Język Polski, 26, 155-156, 1946).

Taszycki, W. (1958b). Słowiańskie nazwy miejscowe (Ustalenie podziału) [Slavic place names (determining the classification)]. W: Taszycki, Rozprawy i studia polonistyczne (t. I, s. 228-268). Wrocław-Kraków: Zakład Narodowy im. Ossolińskich. (Wydanie oryginalne: Prace Komisji Językowej PAU, 29, 1946).

Taszycki, W. (1968). Kilka uwag o nazwach mieszkańców od nazw krain i miejscowości [A few remarks about the names of inhabitants derived from the names of lands and places]. W: W. Taszycki, Rozprawy i studia polonistyczne (t. IV, s. 50-55). Wrocław-Warszawa-Kraków: Zakład Narodowy im. Ossolińskich. (Przedruk z Prace Filologiczne, 18(3), 261-265, 1964).

Tyrpa, A. (2012). Polskie choronimy i etnonimy ludowe [Polish choronyms and folk ethnonyms]. Onomastica, 56, 25-52. 
Wolnicz-Pawłowska, E. (2016). Terminologia onomastyczna w tradycji badawczej i praktyce normalizacyjnej [Onomastic terminology in the research tradition and in the standardization practise]. Onomastica, 60, 37-46.

W SJP PAN - Wielki stownik języka polskiego PAN [The great dictionary of the Polish language PAS]; https://www.wsjp.pl/ (dostęp: kwiecień 2020).

Zarębski, R. (2003). Etnonimy i nazwy odetniczne w polskich przekładach Nowego Testamentu [Ethnonyms and names of ethnic derivation in Polish translations of the New Testament]. Onomastica, 48, 45-78.

Zawodzińska-Bukowiec, K. (2014). Pseudonim polski (od czasów najdawniejszych do dziś) [The Polish pseudonym (from the earliest times to the present)]. Kraków: Libron.

\section{SUMMARY}

\section{IS THERE A NEED FOR A LEXICOGRAPHIC STUDY OF ANTHROPONOMASTIC TERMS?}

The article discusses basic issues related to Polish anthroponomastic terms, their development and frequency, taking into account the variability of terminological units and the co-existence of native and foreign forms (usually Greek or Latin). It presents problems related to defining a term, determining its scope or (in particular cases) status, indicating preferred, permissible or non-recommended variant forms, selection (reduction) of sub-terms, the existence of doublets with a grammatical number, acceptance or rejection of new terms, etc. In the text, among others, the following sources were used: the dictionary "Osnoven sistem i terminologija na slovenskata onomastika" ["Basic system and terminology of Slavic onomastics"] (1983), an article by Mieczysław Karaś "W sprawie polskiej terminologii onomastycznej" ["On Polish onomastic terminology"] (1968), studies by Henryk Górnowicz (1988) and Ewa Jakus-Borkowa (1987), encyclopedia "Polskie nazwy własne" ["Polish proper names"] (1998), the compendium "Słowiańska onomastyka" ["Slavic onomastics"] (2002-2003) and selected articles published in the journal "Onomastica".

The second part of the article presents the history, scope and definitions of the term ethnonym // ethnic name (based on selected compendia, monographs and contributory studies), paying attention to the types of names it covers. In addition, a preliminary structure of an entry in the terminological dictionary has been outlined, including such elements as: the term, its definition, variability // equivalent term, origin // explanation, its English equivalent, examples // usage, context of use, and additional aspects.

Keywords: anthroponomastics, terminological dictionary, entry structure, ethnonym 